\title{
In vitro Response of the Human Breast Cancer Cell Line MDAMB-231 and Human Peripheral Blood Mononuclear Cells Exposed to ${ }^{60} \mathrm{Co}$ at Single Fraction
}

\author{
Lídia Maria Andrade ${ }^{1 *}$, Tarcisio Passos Ribeiro de Campos ${ }^{1}$, M. F. Leite ${ }^{2}$ and A. M. Góes ${ }^{3}$ \\ ${ }^{I}$ Department of Nuclear Engineering; lídia.andrade@unifenas.br; ${ }^{2}$ Department of Physiology and Biophysics; ${ }^{3}$ \\ Department of Biochemistry and Immunology; Universidade Federal de Minas Gerais; Av. Antônio Carlos, 6627; \\ Campus Pampulha; Prédio PCA1; Sala 2285; 31270-901; Belo Horizonte - MG - Brasil
}

\begin{abstract}
Radiotherapy using gamma rays is a common modality of breast cancer treatment. The aim of this research is to investigate the biological response of the human breast cancer cell line MDAMB-231 and human peripheral blood mononuclear cells (PBMC) exposed in vitro to ${ }^{60}$ Co irradiation at a single fraction of 10 Gy, 25 Gy and 50 Gy doses at 136,4 cGy. $\mathrm{min}^{-1}$ rate. Cells were irradiated at room temperature by the Theratron 80 radiotherapy system. Biological response was evaluated through cellular viability using MTT assay and nucleus damages visualized by Propidium Iodide assay and electrophoresis agarose gel after gamma irradiation. Nucleus damages induced by ${ }^{60}$ Co irradiation were compared to damage caused by cell exposure to $10 \%$ methanol. The 50 Gy dose of irradiation did not stimulate nuclus damages at the same level as that affected by $10 \%$ methanol induction in the MDAMB-231. Further studies are necessary to understand these mechanisms in the MDAMB-231 human breast carcinoma cell line.
\end{abstract}

Key words: Breast Cancer, MDAMB-231, PBMC and Gamma rays

\section{INTRODUCTION}

The malignant breast tumor is the most frequent disease found mostly in 45-65 year-old women all over the world (Harris and Norton, 1997; Lester and Cotran, 1999). Breast cancer is a public health issue in South America, involving about 70.000 cases of which 30.000 are fatal according to WHO database (Jones and Burnett, 1990, Schwartsmann, 2001). Argentina is one of the countries of the world that presents a major incidence of breast cancer, while in Brazil, breast cancer also reaches a high-level of incidence, followed by skin and lung cancer (Lester and Cotran, 1999, Tessaro et al., 2001; Vasconcelos et al., 2001). The surgical method associated with radiotherapy and chemotherapy is the primary clinical intervention in patients without distant metastasis (Way, 1991). Radiotherapy is recommended as standard treatment after breast conserving surgery using two tangential fields in 25-29 fractions of 2 Gy up to total dose of 50-58 Gy spread over a total treatment period of 33-39 days. Locoregional control is observed with a 45 Gy to 50 Gy photon dose (Moss and Cox, 1989, Fredriksson et al, 2001, Koukourakis and Yannakakis, 2001).

Radiation effects on cells have been studied in vitro using variable techniques (Hall, 1988). Exposure of normal cells to ionizing radiation

* Author for correspondence 
leads to a variety of biological effects that include cell cycle arrest, transformation and cell death (Gomes and Milanez, 1997). Damage of DNA cells, induced by irradiation, was found through investigation of base modifications in the DNA cells exposed to low LET ${ }^{60} \mathrm{Co}$ gamma rays and high LET ${ }^{12} \mathrm{C}^{+6}$ particle radiation, generating degradation products after these irradiation types (Pouget et al, 2002). The in vitro effects on cancerous cells at low doses of photon irradiation were investigated, such as the MDAMB-231 human breast carcinoma and PC-3 prostate carcinoma with $5 \mathrm{~Gy}$, as well as the human melanoma and squamous cell carcinoma with ${ }^{60} \mathrm{Co}$ at 7 Gy (Mantha et al, 1999, Binder et al, 2000). However, gamma rays can present radioresistance in cell lines using low doses, as found in two bladder carcinoma cells after $2 \mathrm{~Gy}{ }^{137} \mathrm{Cs}$ exposure (Gupta et al, 2000). Human blood cells have been used for studies on ionizing radiation. Peripheral blood mononuclear cells (PBMC) irradiated with gamma rays are commonly used as feeding cells during the cloning of $\mathrm{T}$ lymphocytes and lymphokine activated killer cells (Chong et al, 1991). Moreover, DNA fragmentation in human lymphocytes induced by low doses of gamma rays can be measured with pulsed field gel electrophoresis, and apoptotic fragments can be detected after irradiation (Belyaev and Ringdahl, 2002)

The relationship between tumor radiosensitivity and apoptosis has been evaluated in several tumor cell lines (Zhivotovsky et al, 1999). It was proven that caspase 8 inhibitor partially prevented apoptosis in Ataxia Telangiectasia cells and in normal lymphocytes exposed to low doses of radiation, and cyclin B1 protein levels rapidly increased during gamma irradiation with a 2 Gy dose in a human Burkitt's lymphoma line, promyelocytic leukemia cell and thymocytes (Albanese and Dainak, 2000).

The in vitro responses after irradiation are important for understanding the cellular effects of ionizing radiation. In the current work, the biological response of non-fractionated gamma rays doses, by the Theratron 80 radiotherapy system, on cell line MDAMB-231 and PBMC were investigated.

\section{MATERIALS AND METHODS}

\section{Cell Culture}

The MDAMB-231, a human breast carcinoma cell line obtained by ATCC, was donated by the Pharmacology Department of the Instituto de Ciências Biológicas of the Universidade Federal de Minas Gerais (ICB-UFMG). PBMC was collected from five 20-30 year-old health volunteers in heparinized blood tubes. Studies involving human specimen were conducted with the informal consent of all donors, and allowed by the "ethics committee on human subjects" at the Universidade Federal de Minas Gerais (UFMG). Cell cultures were maintained in RPMI-1640 medium (Sigma Chemical Company) supplemented with $10 \%$ Fetal Bovine Serum FBS (Laborclin $\left.{ }^{\circledR}\right)$ and antibiotics gentamicin (50 $\mu \mathrm{g} / \mu \mathrm{L})$, penicillin $(500 \mathrm{U} / \mathrm{mL})$ and streptomycin (500 mg/mL), obtained from Sigma Chemical Company, in T-25 tissues culture flasks, from Costar ${ }^{\circledR}$, in a humidified atmosphere containing $5 \% \mathrm{CO}_{2}$ at $37{ }^{0} \mathrm{C}$. The medium was changed every 2-3 days.

\section{PBMC Isolation}

The $40 \mathrm{~mL}$ of blood were collected in heparinized blood tubes. The blood was centrifuged at $500 \mathrm{~g}$ (Jouan CR 412 centrifuge) during $40 \mathrm{~min}$ at $20{ }^{\circ} \mathrm{C}$. After centrifugation, PBMC were isolated using density-gradient centrifugation in Ficoll-Hypaque (Sigma, Sanofi Winthrop). The cells were washed with $40 \mathrm{~mL}$ of MEM and centrifuged at $500 \mathrm{~g}$ for $10 \mathrm{~min}$ at $20{ }^{\circ} \mathrm{C}$ and washed twice with $20 \mathrm{~mL}$ of RPMI. The PBMC was plated in a T-25 flask containing RPMI supplemented with 10\% FBS and maintained in a humidified atmosphere containing $5 \% \mathrm{CO}_{2}$ at $37{ }^{\circ} \mathrm{C}$ for up to five days.

\section{${ }^{60}$ Co Irradiation}

The irradiation was performed by the Theratron 80 radiotherapy system (Atomic Energy Canada Limited) at the São Francisco Radiotherapy Institute (Brazil) with $20 \times 20 \mathrm{~cm}^{2}$ field at 136.4 cGy. $\mathrm{min}^{-1}$ dose rate and surface-source distance of $70 \mathrm{~cm}$. The Theratron ${ }^{60} \mathrm{Co}$ source presented an activity of $130 \mathrm{TBq}$. The cells were exposed to doses of $10 \mathrm{~Gy}, 25 \mathrm{~Gy}$ and $50 \mathrm{~Gy}$ at room temperature for MTT assay and 10 Gy and 50 Gy for other assays. After exposure the cells were returned to the $\mathrm{CO}_{2}$ incubator. 


\begin{abstract}
MTT Assay
The MDAMB-231 and PBMC cells were removed from the T-25 flasks and quantified by a hemocytometer. The $1 \times 10^{4}, 1 \times 10^{5}$ and $1 \times 10^{6}$ cells were loaded in a 96-well plate (Corning $\left.{ }^{\circledR}\right)$ and irradiated with gamma rays. After the irradiation the cells were maintained in $5 \% \mathrm{CO}_{2}$ at $37{ }^{\circ} \mathrm{C}$. Cellular viability was evaluated 1 hour, 24 hours, 48 hours and 72 hours after irradiation. At the indicated times, MTT $(5 \mathrm{mg} / \mathrm{mL})$ from Sigma Chemical Company was added to the cells, which were incubated for 2 hours. This assay is based on the capacity of cells to reduce 3-(4,5dimethylthiazol-2yl)-2,5-diphenyltetrazolium

bromide to formazan, a purple crystal metabolized by mitochondria that can be easily visualized in the viable cells by inverse optical microscopy. This assay measures cellular viability by addition of $10 \% \mathrm{SDS}-\mathrm{HCl}$ to the cells and further incubation at $37{ }^{\circ} \mathrm{C}$ in $5 \% \mathrm{CO}_{2}$ for 18 hours. The solubilized formazan crystals can be determined from the optical density at $595 \mathrm{~nm}$ in an ELISA reader.
\end{abstract}

\section{Propidium Iodide Assay}

MDAMB-231 and PBMC cells were incubated for 24 hours and 72 hours after gamma irradiation with 10 Gy and 50 Gy doses. The cells were washed with $5 \mathrm{~mL}$ of PBS (Sigma Chemical Company) and incubated for $5 \mathrm{~min}$ at room temperature with $50 \mu \mathrm{g} / \mathrm{mL}$ Propidium Iodide (Calbiochem Inc) - a fluorescent dye that stains nuclei of damaged cells. The cells were washed again and damaged nuclei were viewed with an Olympus I x 70 Fluorescence Microscope. Photographic images were taken using Kodak film (Ektachrome, 100 ASA). Counting stained cell nuclei by hemocytometer, for each specific time and dose, yielded the number of nuclei-damaged cells. To compare nuclei damages induced by irradiation with damages induced by other methods, cells were incubated during 12 hours in RPMI supplemented with $10 \%$ methanol used for the propidium iodide assay and electrophoresis agarose gel.

\section{DNA laddering by electrophoresis agarose gel} MDAMB-231 and PBMC DNA samples were isolated from T-25 culture flasks after $10 \mathrm{~Gy}$ and 50 Gy of gamma irradiation for 24 hours and 72 hours, as well as the samples treated with RPMI supplemented with $10 \%$ methanol. The cells were removed using a cell-scraper (Becton Dickinson Company). The samples were washed with $5 \mathrm{~mL}$ of PBS. The cells were homogenized using 250 $\mu \mathrm{L}$ of lyses buffer $(50 \mathrm{mM}$ Tris-HCl-20 mM EDTA-1\% NP-40, pH 7,4). The samples suffered vortex stirring for $1 \mathrm{~min}$ and were centrifuged for $2 \mathrm{~min}$ at $180 \mathrm{~g}$ (Eppendorf Centrifuge $5415 \mathrm{C}$ ). Twenty $\mu \mathrm{g}$ of RNAse $\mathrm{A}$ was added to the supernatants (Boehringer Mannheim), which were incubated for 2 hours at $37{ }^{\circ} \mathrm{C}$. The samples were treated with phenol-chloroform (1:1) and suffered vortex stirring for $1 \mathrm{~min}$. The samples were centrifuged for $2 \mathrm{~min}$ at $10000 \mathrm{~g}$ (Eppendorf Centrifuge $5415 \mathrm{C}$ ). The supernatants were collected and diluted in a 1/10 volume of the $3 \mathrm{M}$ sodium acetate, $\mathrm{pH}$ 5.2. The DNA was precipitated with ethanol and maintained in a freezer at $-20{ }^{0} \mathrm{C}$ overnight. The samples were centrifuged for $20 \mathrm{~min}$ at $10000 \mathrm{~g}$ and washed with $70 \%$ ethanol. Twenty $\mu \mathrm{L}$ DEPC water was added to each sample. The samples were loaded onto $1.5 \%$ agarose gel containing $50 \mu \mathrm{g} / \mathrm{mL}$ ethidium bromide and run at $70 \mathrm{~V}$ for $60 \mathrm{~min}$ on a Horizon $^{\circledR}$ Gibco BRL horizontal gel electrophoresis apparatus (Life Technologies ${ }^{\mathrm{TM}}$ ). The images were digitalized by ImageMaster ${ }^{\circledR}$ VDS (Amersham Pharmacia Biotech).

\section{Statiscal Analysis}

Data were analyzed by ANOVA or Student $t$ test with the level of significance at $p<0.05$.

\section{RESULTS}

\section{Radiation Effects on the Cellular Viability}

MTT assay was used to study cellular viability by mitochondrial metabolization after exposure of cells to ${ }^{60} \mathrm{Co}$. Fig. 1 shows the formazan crystals formed by viable MDAMB-231 cells after a $50 \mathrm{~Gy}$ dose at the proposed times.

A discreet group of cells metabolizing MTT was observed for 24 hours and a gradual increase in MTT metabolization was observed for 48 hours and 72 hours, respectively. Cellular viability observed at 72 hours after irradiation seemed to be greater than the non-irradiated control cells. The same pattern of MTT metabolization was observed when cells were irradiated with 10 Gy and 25 Gy (data not shown).

The MDAMB-231 and PBMC cellular viability 
measured by the optical density at $595 \mathrm{~nm}$ after gamma irradiation is presented in Fig.2. Progressive viability growth was observed in the MDAMB-231 non-irradiated control cells. Similar levels of cellular viability were observed for 1 hour, 24 hours and 48 hours after irradiation with $10 \mathrm{~Gy}$ and $25 \mathrm{~Gy}$. An increase in cellular viability was observed for 48 hours with a 50 Gy dose. At 72 hours after irradiation, the growth in cellular viability was equivalent for all doses tested, and with $50 \mathrm{~Gy}$, viability growth was larger than that of the non-irradiated control.

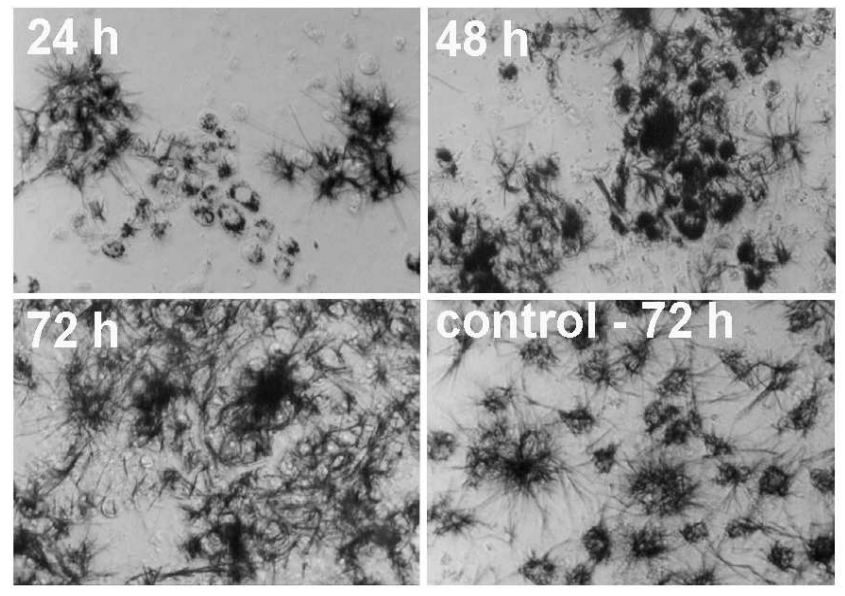

Figure 1 - MDAMB-231 cell cellular viability after gamma irradiation. Cells were plated in $1 \times 10^{6}$ density for 12 hours before gamma irradiation with $10 \mathrm{~Gy}, 25 \mathrm{~Gy}$ and 50 Gy. At the proposed times post-irradiation viable cells were evaluated by MTT assay. Photomicrograph in optical inverse microscopy (X 400) shows formazan's crystals formed after 50Gy by mitochondrial metabolization. Several amounts of viable cells were observed in the different periods. After 72 hours formazan crystals formed in viable cells were greater than non-irradiated control cells for the period

This profile was also observed when cells were plated with other cell densities (data not shown). A reduction in cellular viability of the PBMC nonirradiated control cells was observed. For 72 hours an intense decrease in the cellular viability was observed with $50 \mathrm{~Gy}$, as well as with the other cell densities, times and doses tested (data not shown).

\section{Propidium Iodide Assay}

Nuclear damages were investigated through nuclear staining with propidium iodide. Irradiated MDAMB-231 cells in phase contrast, cells stained with propidium iodide and merged images showing damaged and intact cells are presented in
Fig. 3. Nuclear damages induced by $10 \%$ methanol added to RPMI were observed in cells. An insert shows a detail of chromatin fragmentation, indicative of nuclear damage.

The percentage of damaged cells was quantified after different doses of irradiation. The percentage of nuclear damage in MDAMB-231 cells after gamma irradiation and after induction with $10 \%$ methanol viewed by fluorescence microscopy is presented in Table 1. The percentage of damaged nuclei in PBMC cells after gamma irradiation and after induction with $10 \%$ methanol can be seen in Table 2. 
A MDAMB-231 Cellular Viability
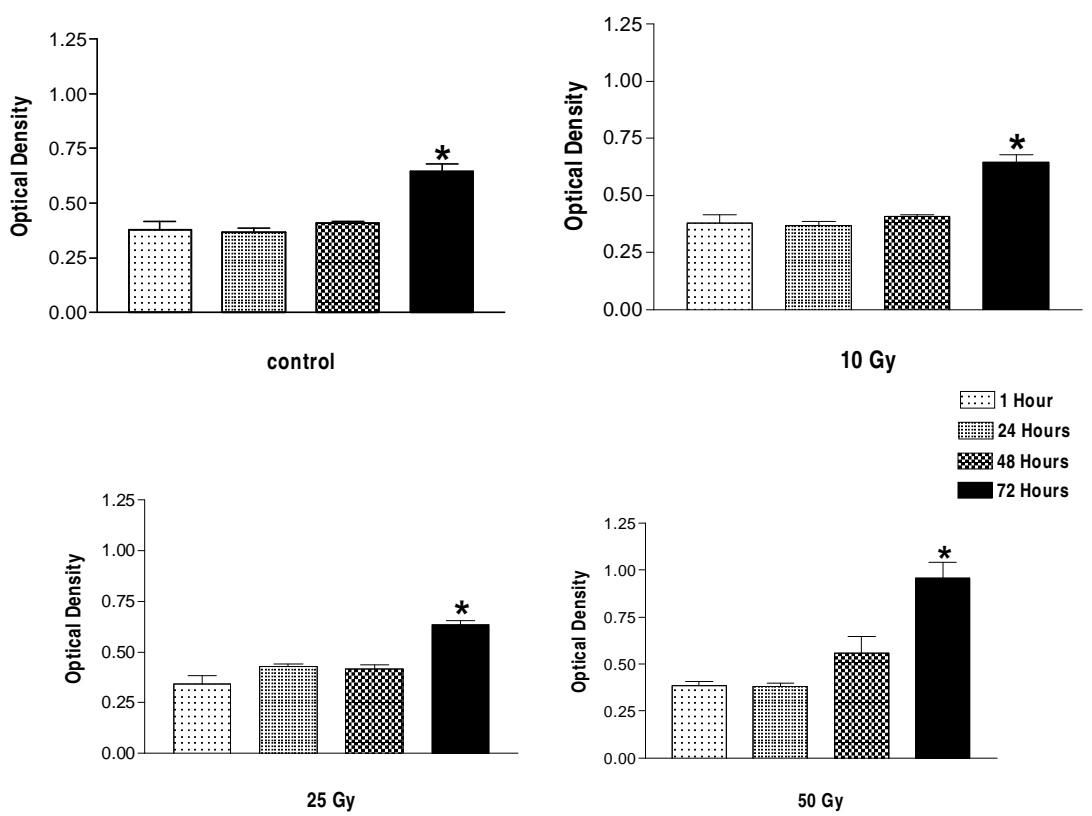

B PBMC Cellular Viability

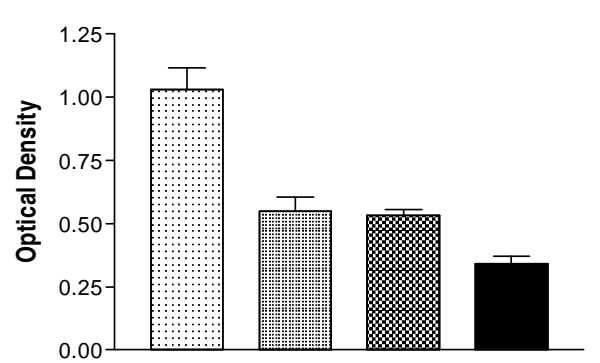

control

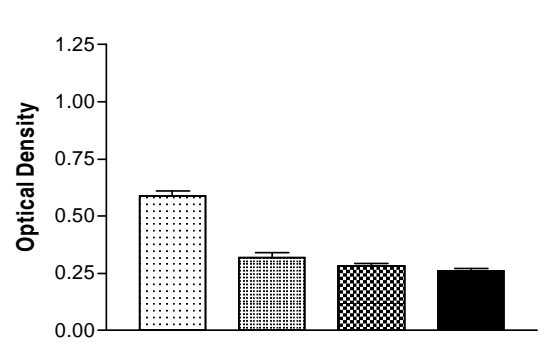

25 Gy

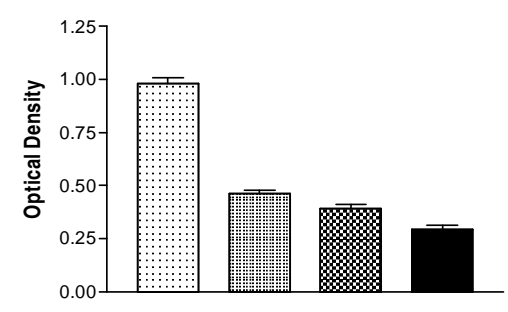

10 Gy

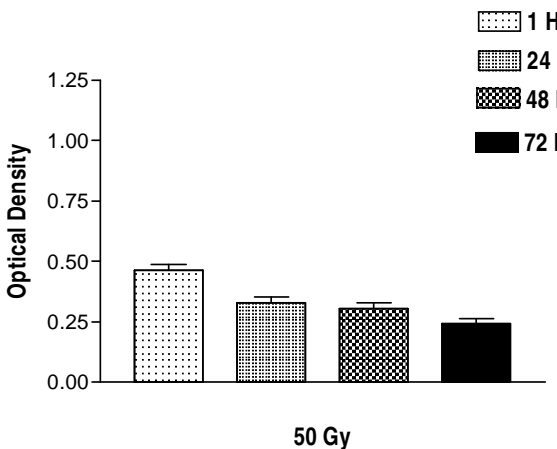

Figure 2 - Measure of cellular viability of MDAMB-231 and PBMC cells through optical density at $595 \mathrm{~nm}$, based on solubilized formazan crystals. Panel A, MDAMB231 optical density in $1 \times 10^{6}$ cells. Panel B, PBMC optical density in $1 \times 10^{6}$ cells. Results represent the mean \pm standard error (Mean \pm SE) of quadruplicates from three experiments and $(*)$ indicates a significative difference at $\mathrm{p}<0.05$. 


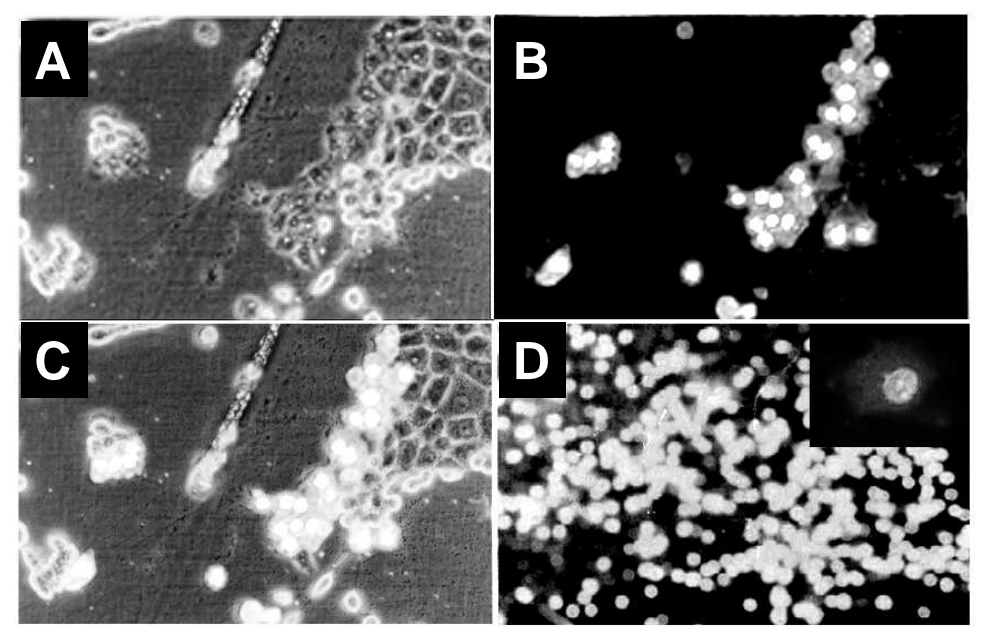

Figure 3 - Propidium iodide stained MDAMB-231 cells. Photomicrograph in inverse fluorescence microscopy (X 400). These cells were stained for 72 hours after 50 Gy gamma irradiation. Panel A, cells in phase contrast. Panel B, the fluorescence field with damaged nuclei stained by propidium iodide. Panel C, merging of these fields with damaged and intact cells positioned. Panel D, nuclear damages induced by treatment with $10 \%$ methanol in fluorescence field and an insert showing chromatin condensation after nuclear damage

Table 1 - Percentage of damaged nuclei found in MDAMB-231 cells 72 hours after irradiation by ${ }^{60}$ Co.

\begin{tabular}{|c|c|c|c|}
\hline \multirow[b]{2}{*}{ Cell treatment } & \multicolumn{2}{|c|}{ Number of nuclei viewed (*) } & \multirow[b]{2}{*}{ Damage (\%) } \\
\hline & Phase contrast & $\begin{array}{c}\text { Fluorescence } \\
\text { field }\end{array}$ & \\
\hline Control & $25,5 \pm 3,1$ & $1,0 \pm 0,1$ & 3,9 \\
\hline $10 G y$ & $25,2 \pm 3,1$ & $14,2 \pm 1,7$ & 56,4 \\
\hline $50 G y$ & $27,5 \pm 3,4$ & $17,7 \pm 2,2$ & 64,5 \\
\hline 10\% Methanol & $19,0 \pm 1,1$ & $18,0 \pm 1,1$ & 95,0 \\
\hline
\end{tabular}

Table 2 - Percentage of damaged nuclei found in PBMC cells 72 hours after irradiation by ${ }^{60}$ Co.

\begin{tabular}{|c|c|c|c|}
\hline \multirow[b]{2}{*}{ Cell treatment } & \multicolumn{2}{|c|}{ Number of nuclei viewed $(*)$} & \multirow[b]{2}{*}{ Damage (\%) } \\
\hline & Phase contrast & Fluorescence field & \\
\hline Control & $17,5 \pm 2,1$ & $7,5 \pm 0,9$ & 42,8 \\
\hline $10 G y$ & $21,0 \pm 2,6$ & $18,7 \pm 2,3$ & 89,2 \\
\hline $50 G y$ & $23,7 \pm 2,8$ & $22,5 \pm 2,8$ & 94,7 \\
\hline $10 \%$ Methanol & $20,0 \pm 0,0$ & $20,0 \pm 0,0$ & 100,0 \\
\hline
\end{tabular}

(*) The data show PBMC cells quantified by hemocytometer as well as percentage of nuclei damaged stained by propidium iodide at room temperature after gamma irradiation. Results represent a standard error (Mean \pm SE) from four experiments. Significative difference at $\mathrm{p}<0.05$. 

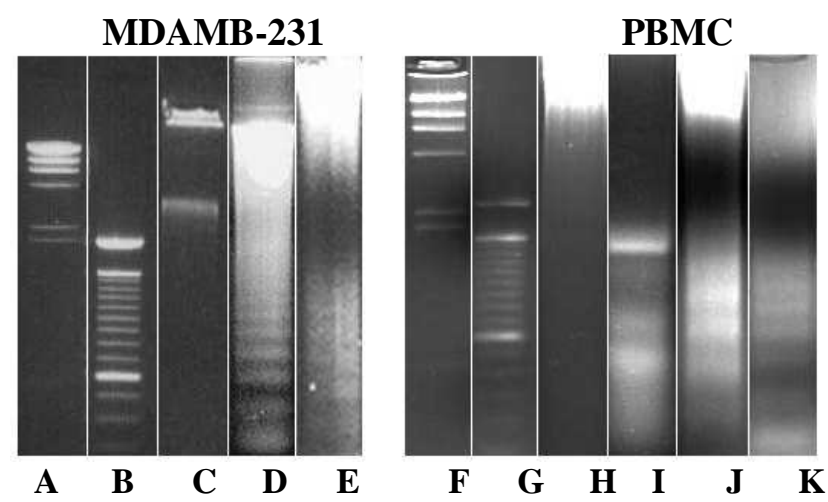

Figure 4 - MDAMB-231 and PBMC cell DNA laddering. (A) Lambda Hind; (B) 100 bp $\left(\mathrm{Gibco}^{\circledR}\right)$; (C) DNA of non-irradiated MDAMB-231 cell; (D) DNA fragmentation of MDAMB-231 treated with $10 \%$ methanol; (E) DNA fragmentation of MDAMB-231 after 72 hours and 50 Gy gamma irradiation; (F) and $(\mathrm{G})$ Lambda Hind and $100 \mathrm{bp}$,respectively; (H) DNA of PBMC nonirradiated cells; (I) DNA fragmentation of PBMC cells treated with $10 \%$ methanol; (J) DNA fragmentation of PBMC cells after 72 hours and $10 \mathrm{~Gy}$ gamma irradiation; (K) DNA fragmentation of PBMC cells after 50 Gy for the period.

\begin{abstract}
DNA laddering by electrophoresis agarose gel DNA laddering of MDAMB-231 and PBMC cells after gamma irradiation, as well as after treatment with $10 \%$ methanol are shown in Fig. 4. DNA laddering was observed for 72 hours and $50 \mathrm{~Gy}$ only in the MDAMB-231. DNA fragmentation of MDAMB-231 induced by gamma irradiation with a 50 Gy dose did not reproduce the DNA fragmentation induced by $10 \%$ methanol. However, DNA fragmentation in PBMC cells was observed with $10 \mathrm{~Gy}$ and $50 \mathrm{~Gy}$, as well as DNA fragmentation induced by $10 \%$ methanol.
\end{abstract}

\section{DISCUSSION}

The results suggest a radioresistent behavior of non-fractionated ${ }^{60} \mathrm{Co}$ protocol for the MDAMB231 cell line at the level of a clinical radiotherapy dose for tumor control. Indeed, the clinical control dose for human breast cancer did not decrease cellular viability in the MDAMB-231 cell line presenting high mitochondrial metabolization. These results suggest that MDAMB-231 cells are able to efficiently correct the damages induced by irradiation and to stay viable, while PBMC cells present an intense decrease in the cellular viability after irradiation. Radioresistance of MDAMB-231 cells were demonstrated by post-irradiation MTT assay in comparison with radiosensitivity of other cell lines (Hunáková et al., 2000; Andrade et al., 2003). Other studies obtained radiation resistant cell clones of MDAMB-231 selected after gamma fractioned irradiation up to doses of $60 \mathrm{~Gy}$ with fractions of $4 \mathrm{~Gy} /$ fraction (Pearce et al, 2001). These cells line can be resistant to a fractioned dose as a single fraction gamma irradiation.

A dose as high as 50 Gy gamma irradiation at single fraction should be enough to induce nuclear damages in the MDAMB-231 similar to damages induced by $10 \%$ methanol, but this effect did not occur. The results show a higher level of damaged nuclei induced by gamma irradiation on PBMC, similar to the damaged nuclei induced by $10 \%$ methanol, demonstrating a radiation sensitivity of the PBMC. Comparing the rate of nuclear damages between PBMC and MDAMB-231, gamma irradiation and $10 \%$ methanol induced more cellular damages in PBMC, while this fact was not observed to MDAMB-231 cells. Sensitivity of human lymphocytes o photons exposure has already been observed t (Nakamura et al, 1991). The percentages of nuclei damaged after irradiation were significantly higher than that of the nonirradiated control $(p<0.05)$. However, these percentages of damaged nuclei induced by gamma irradiation were low compared to damages induced by $10 \%$ methanol, suggesting an efficacious repair mechanism of the MDAMB-231 cells after gamma irradiation of the surviving cells. The DNA 
fragmentations induced by $10 \%$ methanol were better viewed when compared to DNA fragmentations induced by gamma irradiation in MDAMB-231. These data show few ladders, suggesting that it is difficult for the irradiation to break the DNA of these cells. This fact reinforce the the observation that a low level of nuclear damages was induced after MDAMB-231 gamma irradiation when compared to the treatment with $10 \%$ methanol. The assays employed show that the MDAMB-231 cell line was able to survive in spite of having received high doses of gamma rays. In addition, the treatment with $10 \%$ methanol was more effective than ${ }^{60} \mathrm{Co}$ in causing damages to MDAMB-231 cell line.

The bystander effect, presented by irradiated cells in vitro, describes the biological responses of surrounding cells not directly targeted by a radiation insult, as well as the tumor in vivo (Zhivotovsky et al, 1999). On the other hand, radioresistance of tumor cells is a common phenomenon and intrinsic radioresistance of tumor cells has been correlated to a poorer prognosis after radiotherapy (Girinsky et al, 1992, West et al, 1993). Indeed, several breast cancer cases present failure after radiation therapy in spite of the use of standard protocols (Jobsen et al, 2001, Levitt et al, 2003, Andrade et al, 2004). Further studies are necessary to understand the mechanisms of radioresistance in the human breast carcinoma cell line MDAMB-231 to contribute to breast cancer radiation therapy treatment.

\section{ACKNOWLEDGEMENTS}

The authors acknowledge financial support and a scholarship granted by CNPq, CAPES, and FAPEMIG.

\section{RESUMO}

Radioterapia utilizando radiação gama é uma modalidade comum no tratamento do câncer de mama. A proposta deste estudo é investigar a resposta biológica in vitro da linhagem celular MDAMB-231 de câncer de mama humano e células do sangue periférico humano (PBMC) expostas à irradiação pelo $\mathrm{Co}^{60} \mathrm{em}$ frações simples de $10 \mathrm{~Gy}, 25 \mathrm{~Gy}$ e $50 \mathrm{~Gy}$ e $136,4 \mathrm{cGy} \mathrm{min}^{-1}$ rate. As células foram irradiadas a temperatura ambiente usando o equipamento de radioterapia Theratron 80 radiotherapy system. A resposta biológica, após irradiação gama, foi avaliada através do ensaio do MTT para viabilidade celular e o do ensaio com Iodeto de Propídio para visualização do dano nuclear, além da eletroforese em gel de agarose. Os danos nucleares induzidos pelo $\mathrm{Co}^{60}$ foram comparados aos danos causados pela exposição das células à solução de metanol a $10 \%$. Nós observamos que a dose de 50Gy não estimulou a mesma quantidade de danos nucleares que a solução de metanol a $10 \%$ nas células MDAMB231. Maiores estudos são necessários para a compreensão destes mecanismos nas células de câncer de mama humano MDAMB-231.

\section{REFERENCES}

Albanese, J and Dainak, N. (2000) Regulation of TNFRSF6 (Fas) expression in Ataxia Telangiectasia cell by ionizing radiation. Radiat. Res. 154: 616-624.

Andrade, LM, Leite, MF, Goes, AM and Campos, TPR. (2003) Cellular Viability and Apoptosis of Human Breast Cancer MDAMB-231Cell Line After ${ }^{60} \mathrm{Co}$ Irradiation. Acta Microsc.; 12: 43-48.

Andrade, LM, Leite, MF, Campos, TPR. and Goes, AM, MDAMB-231(2004) Biological Response of the Human Breast Cancer Cell Line MDAMB-231 and Human Peripheral Blood Mononuclear Cells Exposed to Co-60 at Unique Fraction .INIS.AIEA

Belyaev, IY and Ringdahl, MH.(2002) A simple and sensitive pulsed field gel electrophoresis protocol to study $50 \mathrm{~kb}$ apoptotic DNA fragmentation in human lymphocytes. Radiat Biol. Radioecol. 42: 279-283.

Binder, AB, Serafin, AM and Bohm, LJF.(2000) Abrogation of $\mathrm{G}_{2} / \mathrm{M}$-phase block enhances the cytotoxicity of daunorubicin, melphalan and cisplatin in TP53 mutant human tumor cells. Radiat. Res. 154: 640-649.

Chong, AS, Bier, DE and Grimes, WJ.(1991) Gammairradiated peripheral blood mononuclear cells can express LAK activity. Int. J. Cell. Clon. 9: 65-77.

Fredriksson, I, Liljergren, G, Arnesson, LG. et al.(2001) Time trends in the results of breast cancer conservation in 4694 women. Eur. J. Cancer. 37:1537-1544.

Girinsky, T, Lubin, R and Pignon, JP.(1992) Predictive value of in vitro radiosensitivity parameters in head and neck cancers and cervical carcinomas: preliminary correlations with local control and overall survival. Int. J. Rad. Oncol. Biol. Phys. 25: 3-7.

Gomes, NGLand Milanez, MC. (1997) Biologia dos tumores. In: Gomes, R. editor. Oncologia Básica. $1^{\text {st }}$ edition, Rio de Janeiro: Revinter. pp.18-35. 
Gupta, AK, Bernhard, EJ, Bakanauskas, VJ, Wu, J, Muschel, RJ and Mckenna, WG. (2000) RASmediated radiation resistance is not linked to MAP kinase activation in two bladder carcinoma cells lines. Radiat. Res. 154: 64-72.

Haddad, N and Silva, M B. Mortalidade por neoplasias em mulheres em idade reprodutiva- 15-49 anos- no estado de São Paulo, Brasil, de 1991 a 1995.(2001) Rev. Ass. Med. Bra. 47: 221-230.

Hall, EJ.(1988) Radiobiology for the radiologist. $1^{\text {st }}$ edition, Philadelphia: Lippincott-Raven.

Harris, J, Morrow, M and Norton, L.(1997) Malignant tumors of the breast. In: De Vita Jr.V, Hellmann, S and Rosenberg, SA editors. Cancer, Principle and Practice of Oncology $5^{\text {th }}$ edition, Philadelphia: Lippincott-Raven. pp 1541-1616.

Hunáková, L, Chorváth, M, Duraj, J et al.(2000) Radiation-induced apoptosis and cell cycle alterations in human carcinoma cell lines with different radiosensitivities. Neoplasma. 47: 25-31.

Jobsen , JJ, Palen, JVD and Meerwaldt, J. H (2001). The impact of age on local control in women with pT1 breast cancer treated with conservative surgery and radiation therapy. Eur. J.Cancer. 37:1820-1827.

Jones, HW, Wents, AC and Burnett, LS.(1990) Novak Tratado de Ginecologia. Rio de Janeiro: Guanabara Koogan.

Koukourakis, MI and Yannakakis, D.(2001) Hypo fractionated and accelerated radiotherapy with ethyol cytoprotection (HYPOARC) for locally advanced breast cancer. Am. Sc. Clin. Oncol. 27 Annual Meeting, 1298.

Lester, SC and Cotran, RS. (1999) The Breast In: Robbins Pathologic Basis of Disease. $6^{\text {th }}$ edition, Philadelphia :W. B. Saunders Company. pp 979-1002.

Levitt, SH, Aeppli, DA and Nierengarten, MB.(2003) Evidence-Based Medicine: Its Effect on Treatment Recommendations as Illustrated by the Changing Role of Postmastectomy Irradiation to Treat Breast Cancer. Int. J. Rad. Oncol. Biol. Phys. 55: 645-650.

Mantha, RLM, Riegel, AT, Suy, S. et al. (1999) Ionizing radiation stimulates octamer factor DNA binding activity in human carcinoma cells. Mol. Cell. Bioch. 199: 209-215.

Moss, WT and Cox, JD.(1989) Radiation oncology. Rationale, technique, results. St. Louis: the C. V. Mosby Company.

Nakamura, N, Sposto, R, Kushiro, JL and Akiyama, M.(1991) Is interindividual variation of cellular radiosensitivity real or artifactual? Radiat. Res. 125: 326-330.

Pearce, AG, Segura, TM., Rintala, AC et al.(2001) The Generation and Characterization of a Radiationresistant Model System to Study Radioresistance in Human Breast Cancer Cells. Radiat.. Res. 156: 739750 .
Porter, LA, Singh, G and Lee, JM.(2000) Abundance of cyclin B1 regulation $\gamma$-radiation induced apoptosis. Blood. 95: 2645-2650.

Pouget, JP, Freton, S, Ravanat JL, Testard, I, Odin, F and Cadet, J.(2002) Formation of Modified DNA Bases in Cells Exposed either to Gamma Radiation or to High-LET Particles. Radiat. Res. 157: 589-595.

Schwartsmann, G. (2001)Breast cancer in South America: challenges to improve early detection and medical management of a public health problem. $J$. Clin. Oncol. 18: 118-124.

Tamamoto, T, Ohnishi, K, Takahashi, A and Wang, X. (1999) Correlation between gamma ray induced G2 arrest and radioresistance in two human cancer cells. Int. J. Rad. Oncol. Biol. Phys. 44: 905-909.

Tessaro, S, Béria, JU, Tomasi, E and Barros, A J D.(2001) Contraceptivos orais e câncer de mlama: estudo de casos e controles. Rev.Saúde Pub. 35: 3238.

Vasconcelos, AB, Mendonça, GA and Sichieri, R.(2001) Height, weight change and risk of breast cancer in Rio de Janeiro, Brazil. São Paulo Med. J. 119: 62-66.

Way, LW.(1991) Current surgical diagnosis and treatment. Applenton Lange.

West, CLM, Davidson, SE, Roberts, SS and Hunter, RD.(1993) Intrinsic radiosensitivity and prediction of patient response to radiotherapy for carcinoma of the cervix. Br. J. Cancer.; 68: 819-823.

Xue, LY, Butler NJ, Makrigiorgos, GM, Adelstein, SJ and Kassis, (2002) AI. Bystander effect produced by radiolabeled tumor cells in vivo. Proc Natl Acad Sci. 99: pp 13765-13770.

Zhivotovsky, B, Joseph, B and Orrentus, (1999) S. Tumor radiosensitivity and apoptosis. Exper. Cell Res. 248: 10-17.
Received: June 30, 2005; Revised: July 14, 2005; Accepted: August 01, 2005. 